\title{
GAMBARAN EFEK PEMBERIAN ANESTESI LOKAL DENGAN TEKNIK BLOK MANDIBULA FISHER PADA PEMINUM ALKOHOL
}

\author{
${ }^{1}$ Ayu S. Gugule \\ ${ }^{2}$ Jimmy Posangi \\ ${ }^{3}$ Ni Wayan Mariati
}

\author{
${ }^{1}$ Kandidat Skripsi Program Studi Kedokteran Gigi Fakultas Kedokteran \\ Universitas Sam Ratulangi Manado \\ ${ }^{2}$ Bagian Faramakologi Fakultas Kedokteran Universitas Sam Ratulangi Manado \\ ${ }^{3}$ Bagian Bedah Mulut Program Studi Kedokteran Gigi Fakultas Kedokteran \\ Universitas Sam Ratulangi Manado \\ Email: ayusulistiawatigugule@yahoo.com
}

\begin{abstract}
The habit of consuming alcoholic beverages have special characteristics when dealing with drugs, especially related to the anesthesia, when compared with those who did not consume alcoholic beverages because alcohol may alter the response to drugs given simultaneously. Anesthetic drugs and alcohol has the same content, namely the content of ether. Ether is a substance that is widely used as an anesthetic in medicine today. This study aims to describe the provision of local anesthetic effects with mandibular block technique fisher drinkers of alcoholic beverages and also to know the reaction to anesthesia and anesthesia reaction ratio. The research was conducted in a non-descriptive statistics, the data processing and analysis is based on data which is then treated observations described qualitatively. The data is processed and presented in tables and described textually. The results of research on the treatment of anesthesia and extraction indicate that there are differences in the duration of time to react calculated from first injection until such time as the disappearance of pain at the time of extraction. Similarly, there are differences in the duration of time when anesthesia is performed on the area of the lips, tongue, buccal mucosa, and lingual mucosa based on the amount of alcohol you drink and the alcohol content.
\end{abstract}

Keywords: Anesthesia, Mandibular block fisher, Alcoholic beverages.

Abstrak: Kebiasaan mengonsumsi minuman beralkohol memiliki karakteristik khusus bila berhubungan dengan obat-obatan, terlebih berkaitan dengan anestesi, jika dibanding dengan orang yang tidak mengonsumsi minuman beralkohol karena alkohol dapat merubah respon terhadap obat yang diberikan secara bersamaan. Obat anestesi dan alkohol mempunyai kandungan yang sama yaitu kandungan eter. Eter ialah suatu zat yang banyak digunakan sebagai anestesi dalam dunia kedokteran hingga saat ini. Penelitian ini bertujuan untuk mengetahui gambaran pemberian efek anestesi lokal dengan teknik blok mandibula fisher pada peminum minuman beralkohol dan juga untuk mengetahui masa reaksi anestesi serta perbandingan reaksi anestesi. Penelitian ini dilakukan secara deskriptif non-statistik, yaitu pengolahan data dan analisis yang didasarkan pada data hasil observasi perlakuan yang kemudian dijelaskan secara kualitatif. Data diolah dan disajikan dalam bentuk tabel serta diuraikan secara tekstual. Hasil penelitian pada perlakuan anestesi dan ekstraksi menunjukkan bahwa terdapat perbedaan durasi masa bereaksi dihitung dari injeksi pertama sampai dengan waktu hilangnya rasa sakit pada saat dilakukan ekstraksi. Begitu pula terdapat perbedaan durasi waktu ketika anestesi dilakukan pada area bibir, lidah, mukosa bukal dan mukosa lingual berdasarkan jumlah alkohol yang diminum serta kandungan kadar alkohol.

Kata kunci: Anestesi, Blok mandibula fisher, Minuman beralkohol. 
Konsumsi minuman yang mengandung alkohol pada daerah-daerah tertentu merupakan bagian integral dari kehidupan bermasyarakat. Di berbagai negara, penjualan minuman beralkohol dibatasi ke sejumlah kalangan saja, umumnya orang-orang yang telah melewati batas usia tertentu, karena minuman beralkohol mengandung etanol. Etanol adalah bahan psikoaktif dan konsumsinya menyebabkan penurunan kesadaran. ${ }^{1}$ Pernyataan di atas menunjukkan bahwa penjualan alkohol bagi masyarakat memiliki batasan-batasan tertentu dalam arti alkohol tidak diperuntukkan bagi semua umur, hal ini karena alkohol bagi tubuh manusia dapat berdampak kurang baik dari aspek kesehatan.

Pada beberapa provinsi mempunyai prevalensi pengguna minuman beralkohol yang tinggi seperti Nusa Tenggara Timur (17,7\%), Sulawesi Utara (17,4\%) dan Gorontalo (12,3\%). ${ }^{2}$ Di Sulawesi Utara khususnya Manado, jenis minuman beralkohol yang banyak dikonsumsi oleh masyarakat adalah minuman Captikus dengan kadar alkohol 40\%-45\%, dan minuman Kasegaran dengan kadar alkohol 17\%.

Kebiasaan minum alkohol ini juga merupakan masalah sosial. ${ }^{3}$ Acara minumminum bagi sebagian masyarakat merupakan suatu kebiasaan di saat santai berkumpul dengan teman-teman, sahabat, kerabat dan dilakukan hampir tiap malam untuk melepas lelah setelah seharian bekerja. Alkohol dikonsumsi kebanyakan oleh lakilaki karena dipengaruhi oleh faktor psikologis, pengaruh lingkungan sosial, ritual masyarakat, menunjukkan kejantanan, mengalihkan diri dari kecemasan dan kebanggaan diri. ${ }^{4}$

Alkohol dalam kaitannya dengan masalah sosial dapat dilihat dalam kehidupan masyarakat. Sering terjadi kasus perkelahian antara pemuda karena dipicu oleh minuman alkohol. Sering terjadi kecelakaan kendaraan bermotor karena disebabkan juga oleh minuman alkohol. Itulah sebabnya ada batasan dan peraturan mengenai penjualan alkohol dalam masyarakat. Walaupun kenyataannya terdapat indikasi dalam masyarakat bahwa penjualan minuman beralkohol sulit untuk dikontrol, akibatnya anggota masyarakat dengan mudah untuk mendapatkan minuman beralkohol.

Dengan penjelasan di atas, kita dapat melihat bahwa hampir sebagian masyarakat tidak begitu tahu bahwa minuman alkohol bisa membahayakan kesehatan mereka. Apa lagi dalam kaitannya dengan kesehatan gigi dan mulut atau penyakit-penyakit sistemik lainnya.

Berbicara kesehatan gigi dan mulut, alkohol memiliki keterkaitan dengan kegiatan praktek dokter gigi, khususnya pemberian anestesi dan ekstraksi. Kegiatan praktek dokter gigi memerlukan pengakuan pasien serta hasil tes laboratorium karena sangat penting untuk mengidentifikasi penyakit yang berhubungan dengan penggunaan alkohol. Interaksi antara alkohol dengan obat dapat terjadi, sehingga harus diperhitungkan secara hati-hati penggunaannya dalam obat, operasi, maupun dalam bidang anestesi. ${ }^{5}$ Dokter yang melakukan tindakan seperti pencabutan gigi atau pembedahan memerlukan anestesi.

Istilah anestesi digunakan pertama kali oleh Oliver Wendel Holmes Sr pada tahun 1846. ${ }^{6}$ Anestesi (pembiusan; berasal dari bahasa Yunani an-“tidak, tanpa" dan aestheos, "persepsi, kemampuan untuk merasa”), secara umum berarti suatu tindakan menghilangkan rasa sakit ketika melakukan pembedahan dan berbagai prosedur lainnya yang menimbulkan rasa sakit pada tubuh. ${ }^{6}$

Obat anestesi dan alkohol mempunyai kandungan yang sama yaitu kandungan eter. Eter ([CH3CH2]2O) ialah suatu zat yang banyak digunakan sebagai anestesi dalam dunia kedokteran hingga saat ini. Alkohol dapat merubah respon terhadap obat yang diberikan bersamaan. ${ }^{3}$ Hal ini dapat terjadi karena adanya interaksi antara alkohol dan obat. $^{3}$

Berdasarkan uraian di atas ternyata bahwa orang yang memiliki kebiasaan mengonsumsi minuman beralkohol memiliki karakteristik khusus bila berhubungan dengan obat-obatan, terlebih berkaitan dengan anestesi, jika dibanding dengan orang yang tidak mengonsumsi minuman alkohol. 
10 Jurnal e-GiGi (eG), Volume 1, Nomor 1, Maret 2013, hlm. 8-17

Dasar pemikiran tersebut melatari penulis, sehingga tertarik untuk melakukan penelitian dengan judul "Gambaran Efek Pemberian Anestesi Lokal dengan Teknik Blok Mandibula Fisher Pada Peminum Alkohol”.

\section{METODE PENELITIAN}

Penelitian ini merupakan penelitian eksperimen atau pre-post test, dimana tujuan penelitian akan menjelaskan tentang anestesi lokal dangan teknik blok mandibula dalam hubungannya dengan pengonsumsi minuman alkohol melalui tindakan atau intervensi medik. Intervensi atau tindakan dilakukan pada sejumlah responden sebagai anggota sampel penelitian yang kemudian dibandingkan hasil sebelum dan sesudah intervensi. $^{7,8}$

Populasi dalam penelitian ini yaitu para anggota masyarakat yang dinyatakan sebagai penduduk desa Poyowa Besar, yang tergolong pengonsumsi minuman beralkohol dan sebagian lagi dari Manado. Anggota sampel penelitian yaitu mereka yang berdasarkan data dari informan tergolong pengonsumsi minuman alkohol dengan jumlah 10 (sepuluh) orang.

Teknik penentuan sampling berdasarkan kriteria sebagai pengonsumsi alkohol. Dari total data populasi penelitian, kemudian ditentukan anggota sampling secara purposive sampling, yaitu melihat tingkat ketergantungan pada minuman alkohol, dengan kategori pengonsumsi ringan ( $>1$ botol perhari), pengkonsumsi sedang (2-3 botol perhari) dan pengonsumsi berat (di atas tiga botol perhari).

Penelitian ini dikhususkan pada perlakuan terhadap orang yang mengonsumsi alkohol baik ringan hingga berat. Perlakuan dimaksud dalam penelitian ini yaitu tindakan anestesi terhadap pengonsumsi alkohol dengan tujuan untuk mengetahui reaksi tindakan anestesi dilihat dari aspek lamanya waktu bereaksi dan area yang mengalami hilangnya rasa sakit. Injeksi dilakukan dengan mendepositkan larutan anestesi di ruang pterigomandibular di dekat foramen mandibula.
Setelah data dan informasi terkumpul dari responden penelitian maka akan dilakukan analisis secara deskriptif nonstatistik, yakni pengolahan data dengan tidak menggunakan analisis statistik. Analisis ini akan memuat varian-varian yang berkaitan dengan angka dan penjumlahan tetapi tidak menggunakan rumus statistik. Angka-angka dan penjumlahan terutama durasi waktu yang diperoleh dalam perlakukan anestesi akan dijelaskan secara kualitatif. Penjelasan dimaksud melalui cara induktif, yakni pengambilan kesimpulan umum berdasarkan hasil pengamatan yang khusus. $^{7}$

\section{HASIL PENELITIAN}

Penelitian ini dilaksanakan berdasarkan prosedur medik dan berada di bawah pengawasan dokter gigi di Rumah Sakit Gigi dan Mulut Manado. Jumlah anggota sampel 10 orang yang terdiri 5 orang anggota sampel berasal dari Kotamobagu dan 5 orang berasal dari Manado. Dengan dua kategori asal anggota sampel maka diperoleh bahwa jenis minuman beralkohol yang dikonsumsi juga berbeda. Jenis minuman beralkohol yang beredar di Kotamobagu yang banyak dikonsumsi yaitu Burung Sakti, sedangkan yang banyak beredar di Manado yaitu Captikus dan Kasegaran. Dari ketiga jenis minuman beralkohol tersebut kandungan alkohol yang tertera dalam kemasan yakni; Captikus 4045\%, Kesegaran 17\% dan Burung Sakti $14 \%$. Kemudian rata-rata anggota sampel melakukan kegiatan minum di waktu malam, walaupun ada beberapa anggota sampel yang minum di waktu siang dan malam. Rata-rata konsumsi perorang setiap hari 1 (satu) sampai dengan 3 (tiga) botol (Tabel 1).

Data observasi untuk pasien 1 (tabel 2) ternyata pada menit kelima, bibir, lidah mukosa bukal dan mukosa lingual telah mengalami kram (tidak rasa sakit) sehingga pada menit ke enam dilakukan ekstraksi. Pasien tersebut dalam kesehariannya menkonsumsi minuman beralkohol rata-rata 1 botol, kenyataan setelah dilakukan anestesi mengalami reaksi yang sangat 
cepat, hanya sekitar 6 menit.

Gambaran untuk pasien kedua (tabel 3) ternyata dilakukan injeksi ampul kedua menit ke XVII setelah dilakukan infiltrasi pada menit ke IV, dan nanti pada menit ke XVIII area mukosa bukal dan mukosa lingual mengalami kram, sehingga pada menit ke XIX dilakukan ekstraksi. Pasien tersebut mengonsumsi alkohol setiap malam 3 botol jenis Captikus atau Kasegaran. Reaksi yang dialami oleh pasien tersebut 19 menit setelah injeksi ampul pertama.

Hasil observasi pasien 3 (tabel 4) menunjukkan bahwa pasien tersebut dilakukan injeksi kedua pada menit ke VII dan menit VIII setelah infiltrasi untuk menghilangkan rasa sakit diarea pencabutan, sehingga pada menit kesembilan dilakukan ekstraksi. Pasien yang bersangkutan mengonsumsi minuman beralkohol jenis Captikus dan Kesegaran sekitar 3 botol setiap malam. Reaksi anestesi tergolong cepat walaupun yang bersangkutan menkonsumsi alkohol sampai
3 botol setiap malam.

Data hasil observasi pasien 4 (tabel 5) memperlihatkan bahwa pasien tersebut dilakukan injeksi ampul kedua pada menit ke XX setelah infiltrasi menit keempat. Menit XXI hilang rasa sakit pada area mukosa bukal dan lingual sehinga pada menit XXII dilakukan ekstraksi. Reaksi anestesi berlangsung XXI menit setelah injeksi ampul pertama. Pasien tersebut mengonsumsi minuman beralkohol rata-rata satu botol setiap malam.

Data observasi pasien 5 (tabel 6) menunjukkan bahwa dilakukan injeksi sebanyak 3 ampul sesudah infiltrasi. Ampul kedua pada menit ke $\mathrm{X}$, ampul ketiga pada menit XX dan ampul ke empat pada menit ke 45, sehingga ekstraksi dapat dilakukan pada menit ke 55. Reaksi anestesi dari injeksi ampul pertama sampai dengan pencabutan gigi 55 menit. Pasien tersebut mengonsumsi alkohol 2 botol setiap malam. Catatan khusus bagi pasien ini ternyata gigi yang bersangkutan terdapat granuloma.

Tabel 1. Kegiatan konsumsi alkohol

\begin{tabular}{lclclcc}
\hline No & Sampel/Pasien & Waktu minum & $\begin{array}{c}\text { Frekuensi } \\
\mathbf{1 x 2 4} \text { jam }\end{array}$ & $\begin{array}{c}\text { Jenis } \\
\text { Minuman }\end{array}$ & $\begin{array}{c}\text { Volume/ } \\
\text { Botol } \\
(\mathbf{6 2 0} \text { ml) }\end{array}$ & Kadar/\% \\
\hline 1 & 1 & malam & 1 & $\mathrm{Ct}, \mathrm{Ks}$ & 1 & $17-45$ \\
2 & 2 & Malam & 1 & $\mathrm{Ks}, \mathrm{Br}$ & 3 & $16-20$ \\
3 & 3 & Malam & 1 & $\mathrm{CT}, \mathrm{KS}$ & 3 & $17-45$ \\
4 & 4 & Malam & 1 & $\mathrm{CT}, \mathrm{KS}$ & 1 & $17-45$ \\
5 & 5 & Malam & 1 & $\mathrm{CT}, \mathrm{KS}$ & 2 & $17-45$ \\
6 & 6 & Siang/malam & 2 & $\mathrm{BS}$ & 2 & 14 \\
7 & 7 & Siang/Malam & 2 & $\mathrm{BS}$ & 2 & 14 \\
8 & 8 & Siang Malam & 2 & $\mathrm{BS}$ & 2 & 14 \\
9 & 9 & Siang/Malam & 2 & $\mathrm{BS}$ & 2 & 14 \\
10 & 10 & Siang/Malam & 2 & BS & 2 & 14 \\
\hline
\end{tabular}

Tabel 2. Hasil observasi pasien 1

\begin{tabular}{|c|c|c|c|c|c|c|c|c|c|}
\hline \multirow{2}{*}{ Area reaksi } & \multirow{2}{*}{$\begin{array}{c}\text { Injeksi/ } \\
\text { Pukul }\end{array}$} & \multicolumn{4}{|c|}{ M e n i t/reaksi } & \multirow{2}{*}{\multicolumn{2}{|c|}{$\begin{array}{c}\text { Ekstraksi } \\
\text { VI }\end{array}$}} & \multirow{2}{*}{ Ampul/cc } & \multirow{2}{*}{ Keterangan } \\
\hline & & $\mathrm{I}$ & II & III & IV & $\mathrm{V}$ & & & \\
\hline Bibir & 12.30 & + & + & + & Infiltrasi & + & Cabut & $2,0 \mathrm{cc}$ & Blok \\
\hline Lidah & $1,5 \mathrm{cc}$ & + & + & + & $0,5 \mathrm{cc}$ & + & gigi & & Mandibula \\
\hline $\begin{array}{l}\text { Mukosa } \\
\text { Bukal }\end{array}$ & & - & - & - & & + & & & $\begin{array}{l}1,5 \text { cc dan } 0,5 \\
\text { cc infiltrasi }\end{array}$ \\
\hline $\begin{array}{l}\text { Mukosa } \\
\text { Lingual }\end{array}$ & & - & + & + & & + & & & \\
\hline
\end{tabular}


12 Jurnal e-GiGi (eG), Volume 1, Nomor 1, Maret 2013, hlm. 8-17

Tabel 3. Hasil observasi pasien 2

\begin{tabular}{|c|c|c|c|c|c|c|c|c|c|c|c|}
\hline \multirow{2}{*}{$\begin{array}{c}\text { Area } \\
\text { reaksi }\end{array}$} & \multirow{2}{*}{$\begin{array}{l}\text { Injeksi } \\
\text { Pukul }\end{array}$} & \multicolumn{5}{|c|}{ M e n i t/reaksi } & \multirow{2}{*}{$\begin{array}{c}\begin{array}{c}\text { Injeksi } \\
\text { pukul }\end{array} \\
\text { XVII }\end{array}$} & \multirow{2}{*}{$\begin{array}{c}\text { Menit/ } \\
\text { reaksi }\end{array}$} & \multirow{2}{*}{$\begin{array}{c}\text { Ekstraksi } \\
\text { XIX }\end{array}$} & \multirow{2}{*}{$\underset{\text { cc }}{\text { Ampul }}$} & \multirow[b]{2}{*}{ Ket } \\
\hline & & I & II & III & $\begin{array}{c}\text { IV, V, } \\
\text { VI }\end{array}$ & VII & & & & & \\
\hline Bibir & $\begin{array}{l}11.15 \\
1,5 \mathrm{cc}\end{array}$ & + & + & + & $\begin{array}{l}\text { Infiltrasi } \\
0,5 \mathrm{cc}\end{array}$ & + & $\begin{array}{l}11.32 \\
0,5 \text { сс }\end{array}$ & + & $\begin{array}{l}\text { Cabut } \\
\text { gigi }\end{array}$ & $\begin{array}{l}2,0 \mathrm{cc} \\
0,5 \mathrm{cc}\end{array}$ & $\begin{array}{l}2 \mathrm{x} \\
\text { injeksi }\end{array}$ \\
\hline Lidah & & + & + & + & & + & & + & & & $2,5 \mathrm{cc}$ \\
\hline $\begin{array}{l}\text { Mukosa } \\
\text { Bukal }\end{array}$ & & + & + & + & & + & & + & & & \\
\hline $\begin{array}{l}\text { Mukosa } \\
\text { Lingual }\end{array}$ & & - & - & - & & - & & + & & & \\
\hline
\end{tabular}

Tabel 4. Hasil observasi pasien 3

\begin{tabular}{|c|c|c|c|c|c|c|c|c|c|c|c|c|}
\hline \multirow{2}{*}{$\begin{array}{l}\text { Area } \\
\text { reaksi }\end{array}$} & \multirow{2}{*}{$\begin{array}{l}\text { Injeksi } \\
\text { Pukul }\end{array}$} & \multicolumn{6}{|c|}{ M e n i t/reaksi } & \multirow{2}{*}{$\begin{array}{c}\begin{array}{c}\text { Injeksi } \\
\text { pukul }\end{array} \\
\text { VII }\end{array}$} & \multirow{2}{*}{$\begin{array}{c}\text { Menit/ } \\
\text { reaksi }\end{array}$} & \multirow{2}{*}{$\begin{array}{c}\text { Ekstraksi } \\
\text { IX }\end{array}$} & \multirow{2}{*}{$\begin{array}{c}\text { Ampul } \\
\text { cc }\end{array}$} & \multirow{2}{*}{ Ket } \\
\hline & & I & II & III & IV & $\mathrm{V}$ & VI & & & & & \\
\hline Bibir & 11.14 & + & + & + & In & + & + & 11.21 & + & Cabut & 2,0 сс & $2 x$ \\
\hline & $1,5 \mathrm{cc}$ & & & & fil & & & 0,5 сс & & gigi & 0,5 сс & injeksi \\
\hline Lidah & & + & + & + & Trasi & + & + & & + & & & $2,5 \mathrm{cc}$ \\
\hline $\begin{array}{l}\text { Mukosa } \\
\text { Bukal }\end{array}$ & & - & - & - & $\begin{array}{l}0,5 \\
\text { сс }\end{array}$ & - & - & & + & & & \\
\hline $\begin{array}{l}\text { Mukosa } \\
\text { Lingual }\end{array}$ & & - & - & - & & + & + & & + & & & \\
\hline
\end{tabular}

Tabel 5. Hasil observasi pasien 4

\begin{tabular}{|c|c|c|c|c|c|c|c|c|c|c|c|c|}
\hline \multirow{2}{*}{$\begin{array}{l}\text { Area } \\
\text { reaksi }\end{array}$} & \multirow{2}{*}{$\begin{array}{l}\text { Injeksi } \\
\text { Pukul }\end{array}$} & \multicolumn{6}{|c|}{ M e n i t/reaksi } & \multirow{2}{*}{$\begin{array}{c}\begin{array}{c}\text { Injeksi } \\
\text { pukul }\end{array} \\
\mathrm{XX}\end{array}$} & \multirow{2}{*}{$\begin{array}{c}\text { Menit/ } \\
\text { reaksi }\end{array}$} & \multirow{2}{*}{$\begin{array}{c}\text { Ekstraksi } \\
\text { XXII }\end{array}$} & \multirow{2}{*}{$\underset{\text { cc }}{\text { Ampul }}$} & \multirow[t]{2}{*}{ Ket } \\
\hline & & $\mathrm{I}$ & II & III & IV & $\mathrm{V}$ & VI & & & & & \\
\hline Bibir & $\begin{array}{l}11.00 \\
1.5 \mathrm{cc}\end{array}$ & + & + & + & $\begin{array}{l}\text { Infil } \\
\text { Trasi }\end{array}$ & + & + & $\begin{array}{l}11.20 \\
0.5 \mathrm{cc}\end{array}$ & + & $\begin{array}{l}\text { Cabut } \\
\text { gigi }\end{array}$ & $\begin{array}{l}2,0 \mathrm{cc} \\
0,5 \mathrm{cc}\end{array}$ & $\begin{array}{l}2 \mathrm{x} \\
\text { inieksi }\end{array}$ \\
\hline Lidah & & + & + & + & 0,5 & + & + & & + & & & $2,5 \mathrm{cc}$ \\
\hline $\begin{array}{l}\text { Mukosa } \\
\text { Bukal }\end{array}$ & & - & - & - & $\mathrm{CC}$ & - & - & & + & & & \\
\hline $\begin{array}{l}\text { Mukosa } \\
\text { Lingual }\end{array}$ & & - & - & + & & + & + & & + & & & \\
\hline
\end{tabular}

Data hasil observasi pasien 6 (tabel 7) memperlihatkan bahwa pasien tersebut dilakukan ektraksi pada menit ke IX. Konsumsi alkohol bagi yang bersangkutan rata-rata 2 (dua) botol setiap hari. Reaksi anestesi tergolong cepat karena hanya memakan waktu 8 menit setelah injeksi ampul pertama.

Data hasil observasi pasien 7 (tabel 8) menunjukan reaksi anestesi berdurasi enam menit, dua menit setelah infiltrasi. Ekstraksi dilakukan pada menit ke tujuh. Konsumsi alkohol bagi yang bersangkutan rata-rata 2 botol setiap hari.

Berdasarkan data observasi pasien 8 (tabel 9), ternyata pasien yang bersangkutan dilakukan injeksi ampul kedua (5cc) pada menit ke $\mathrm{X}$ dan ampul ketiga pada menit ke 
XX. Hilang rasa sakit pada menit ke XXII dan XXIII, sehingga ekstraksi dilakukan pada menit ke XXIV. Yang bersangkutan mengonsumsi minuman beralkohol rata-rata 2 botol setiap hari.

Hasil data observasi pasien 9 (tabel 10) menunjukkan bahwa, pasien tersebut merasakan reaksi pada menit ke VI setelah dilakukan infiltrasi pada menit ke IV dan menit ke V. Kemudian pada menit ke VII sudah dilakukan ekstraksi. Pasien tersebut mengonsumsi minuman beralkohol rata-rata 2 botol per hari.

Data observasi pasien 10 (tabel 11) menunjukkan bahwa pasien tersebut merasakan reaksi pada menit ke XV, setelah dilakukan ifiltrasi pada menit ke VI. Ekstraksi dilakukan pada menit ke XVI. Pasien tersebut mengonsumsi minuman beralkohol pada waktu siang dan malam dengan volume rata-rata dua botol satu hari.

Tabel 6. Hasil observasi pasien 5

\begin{tabular}{|c|c|c|c|c|c|c|c|c|c|c|c|c|}
\hline \multirow{2}{*}{$\begin{array}{l}\text { Area } \\
\text { reaksi }\end{array}$} & \multirow{2}{*}{$\begin{array}{l}\text { Injeksi } \\
\text { Pukul }\end{array}$} & \multicolumn{6}{|c|}{ M e n i t/reaksi } & \multirow{2}{*}{$\begin{array}{c}\begin{array}{c}\text { Injeksi } \\
\text { pukul }\end{array} \\
X\end{array}$} & \multirow{2}{*}{$\begin{array}{c}\begin{array}{c}\text { Injeksi } \\
\text { pukul }\end{array} \\
X X\end{array}$} & \multirow{2}{*}{$\begin{array}{c}\begin{array}{c}\text { Injeksi } \\
\text { pukul }\end{array} \\
X X X X V \\
\end{array}$} & \multirow{2}{*}{$\begin{array}{l}\text { Ekstraksi } \\
X X X X X V\end{array}$} & \multirow[t]{2}{*}{ Ket } \\
\hline & & I & II & III & IV & V & VI & & & & & \\
\hline Bibir & 11.30 & - & - & _- & Infil & + & + & 11.40 & 11.50 & 12,15 & Cabut & $4 \mathrm{x}$ \\
\hline Lidah & 1,5 сс & _- & - & - & Trasi & - & - & 0,5 сс & $0,5 \mathrm{cc}$ & 0,5 сс & gigi & injeksi \\
\hline $\begin{array}{l}\text { Mukosa } \\
\text { Bukal }\end{array}$ & & - & + & + & 0,5 & + & + & & & & & 3,5 сс \\
\hline $\begin{array}{l}\text { Mukosa } \\
\text { Lingual }\end{array}$ & & - & - & - & & - & - & & & & & \\
\hline
\end{tabular}

Tabel 7. Hasil observasi pasien 6

\begin{tabular}{|c|c|c|c|c|c|c|c|c|c|c|c|c|}
\hline \multirow{2}{*}{$\begin{array}{c}\text { Area } \\
\text { reaksi }\end{array}$} & \multirow{2}{*}{$\begin{array}{l}\text { Injeksi } \\
\text { Pukul }\end{array}$} & \multicolumn{8}{|c|}{ M e n i t/reaksi } & \multirow{2}{*}{$\frac{\text { Ekstraksi }}{\text { IX }}$} & \multirow{2}{*}{$\begin{array}{c}\text { Ampul } \\
\text { cC }\end{array}$} & \multirow{2}{*}{ Ket } \\
\hline & & I & II & III & IV & $\mathrm{V}$ & VI & VII & VIII & & & \\
\hline Bibir & 11.20 & - & - & - & In & + & + & + & + & Cabut & 1,5 сс & $1 \mathrm{x}$ \\
\hline Lidah & $1,5 \mathrm{cc}$ & - & + & + & fil & + & + & + & + & gigi & 0,5 сс & injeksi \\
\hline $\begin{array}{l}\text { Mukosa } \\
\text { Bukal }\end{array}$ & & - & - & - & $\begin{array}{l}\text { Trasi } \\
0,5 \mathrm{cc}\end{array}$ & - & - & + & + & & & 2,0 cc \\
\hline $\begin{array}{l}\text { Mukosa } \\
\text { Lingual }\end{array}$ & & - & - & - & & - & - & + & + & & & \\
\hline
\end{tabular}

Tabel 8. Hasil observasi pasien 7

\begin{tabular}{|c|c|c|c|c|c|c|c|c|c|c|}
\hline \multirow{2}{*}{$\begin{array}{c}\text { Area } \\
\text { reaksi }\end{array}$} & \multirow{2}{*}{$\begin{array}{c}\text { Injeksi } \\
\text { Pukul }\end{array}$} & \multicolumn{6}{|c|}{ M e n i t/reaksi } & \multirow{2}{*}{$\frac{\text { Ekstraksi }}{\text { VII }}$} & \multirow{2}{*}{$\begin{array}{c}\text { Ampul } \\
\text { cc }\end{array}$} & \multirow[t]{2}{*}{ Ket } \\
\hline & & I & II & III & IV & $\mathrm{V}$ & VI & & & \\
\hline Bibir & 11.00 & + & + & + & Infil & + & + & Cabut & $1,5 \mathrm{cc}$ & $1 \mathrm{x}$ injeksi \\
\hline Lidah & $1,5 \mathrm{cc}$ & + & + & + & Trasi & + & + & gigi & 0,5 сc & $2,0 \mathrm{cc}$ \\
\hline $\begin{array}{l}\text { Mukosa } \\
\text { Bukal }\end{array}$ & & - & - & - & $0,5 \mathrm{cc}$ & + & + & & & \\
\hline $\begin{array}{l}\text { Mukosa } \\
\text { Lingual }\end{array}$ & & - & - & - & & + & + & & & \\
\hline
\end{tabular}


14 Jurnal e-GiGi (eG), Volume 1, Nomor 1, Maret 2013, hlm. 8-17

Tabel 9. Hasil observasi pasien 8

\begin{tabular}{|c|c|c|c|c|c|c|c|c|c|c|c|c|}
\hline \multirow{2}{*}{$\begin{array}{c}\text { Area } \\
\text { reaksi }\end{array}$} & \multirow{2}{*}{$\begin{array}{c}\text { Injeksi } \\
\text { Pukul }\end{array}$} & \multicolumn{6}{|c|}{ M e n i t/reaksi } & \multirow{2}{*}{$\begin{array}{c}\begin{array}{c}\text { Injeksi } \\
\text { pukul }\end{array} \\
X\end{array}$} & \multirow{2}{*}{$\begin{array}{c}\begin{array}{c}\text { Injeksi } \\
\text { pukul }\end{array} \\
X X\end{array}$} & \multirow{2}{*}{$\begin{array}{c}\text { Ekstraksi } \\
\text { XXIV }\end{array}$} & \multirow{2}{*}{$\begin{array}{c}\text { Ampul } \\
\text { CC }\end{array}$} & \multirow{2}{*}{ Ket } \\
\hline & & I & II & III & IV & V & VI & & & & & \\
\hline Bibir & 11.17 & - & + & + & Infil & + & + & 11.27 & 11,37 & Cabut & $2,0 \mathrm{cc}$ & $3 x$ \\
\hline Lidah & 1,5 сc & - & + & + & Trasi & + & + & $0,5 \mathrm{cc}$ & 0,8 & gigi & 0,5 сс & injeksi \\
\hline $\begin{array}{l}\text { Mukosa } \\
\text { Bukal }\end{array}$ & & - & - & - & $0,5 \mathrm{cc}$ & - & + & & & & 0,8 & 3,2 сc \\
\hline $\begin{array}{l}\text { Mukosa } \\
\text { Lingual }\end{array}$ & & - & - & - & & - & + & & & & & \\
\hline
\end{tabular}

Tabel 10. Hasil observasi pasien 9

\begin{tabular}{|c|c|c|c|c|c|c|c|c|c|}
\hline \multirow{2}{*}{$\begin{array}{c}\text { Area } \\
\text { reaksi }\end{array}$} & \multirow{2}{*}{$\begin{array}{c}\text { Injeksi } \\
\text { Pukul }\end{array}$} & \multicolumn{5}{|c|}{ M e n i t/reaksi } & \multirow{2}{*}{$\frac{\text { Ekstraksi }}{\text { VII }}$} & \multirow{2}{*}{$\begin{array}{c}\text { Ampul } \\
\text { cc }\end{array}$} & \multirow{2}{*}{ Ket } \\
\hline & & I & II & III & $\mathrm{IV}, \mathrm{V}$ & VI & & & \\
\hline Bibir & 11.30 & - & - & + & Infiltrasi & + & Cabut & $2,0 \mathrm{cc}$ & $1 \mathrm{x}$ injeksi \\
\hline Lidah & 1,5 cc & + & + & + & $0,5 \mathrm{cc}$ & + & gigi & & $2.0 \mathrm{cc}$ \\
\hline Mukosa & & _- & + & + & & + & & & \\
\hline Bukal & & & & & & & & & \\
\hline $\begin{array}{l}\text { Mukosa } \\
\text { Lingual }\end{array}$ & & - & - & - & & + & & & \\
\hline
\end{tabular}

Tabel 11. Hasil observasi pasien 10

\begin{tabular}{|c|c|c|c|c|c|c|c|c|c|c|c|}
\hline \multirow{2}{*}{$\begin{array}{l}\text { Area } \\
\text { reaksi }\end{array}$} & \multirow{2}{*}{$\begin{array}{c}\text { Injeksi } \\
\text { Pukul } \\
\end{array}$} & \multicolumn{6}{|c|}{ M e n i t/reaksi } & \multirow{2}{*}{$\begin{array}{c}\text { Injeksi } \\
\text { Pukul } \\
\end{array}$} & \multirow{2}{*}{$\begin{array}{c}\text { Ekstraksi } \\
\text { XVI } \\
\end{array}$} & \multirow{2}{*}{$\begin{array}{c}\text { Ampul } \\
\text { cc }\end{array}$} & \multirow{2}{*}{ Ket } \\
\hline & & I & II & III & IV & $\mathrm{V}$ & VI & & & & \\
\hline Bibir & 11. & - & + & + & + & + & Infilt & 11,15 & Cabut & 2,0 cс & $2 x$ \\
\hline Lidah & 1,5 сс & - & _ & + & + & + & rasi & $1 \mathrm{cc}$ & gigi & 1,0 сс & injeksi \\
\hline $\begin{array}{l}\text { Mukosa } \\
\text { Bukal }\end{array}$ & & - & - & - & - & + & $0,5 \mathrm{cc}$ & & & & $3.0 \mathrm{cc}$ \\
\hline $\begin{array}{l}\text { Mukosa } \\
\text { Lingual }\end{array}$ & & - & - & - & - & - & & & & & \\
\hline
\end{tabular}

\section{BAHASAN}

Berdasarkan uraian hasil penelitian yang telah dipaparkan di atas, maka penulis perlu membahas secara menyeluruh data dan hasil observasi terutama berkaitan dengan masalah atau parameter penelitian. Pembahasan di arahkan pada aspek latar belakang anggota sampel, jenis minuman serta data hasil observasi pelaksanaan pengobatan atau kegiatan pencabutan gigi khususnya keterkaitan antara penkonsumsi minuman beralkohol dengan anestesi dan ekstraksi.

Anggota sampel penelitian berasal dari dua daerah yang berbeda, yaitu Kotamobagu dan Manado. Perbedaan tersebut terlihat pada jenis minuman beralkohol yang beredar di masyarakat. Untuk Kota Kotamobagu jenis Minuman yang beredar dan dengan mudah dapat diakses oleh anggota masyarakat (pengonsumsi alkohol) adalah Burung Sakti (merek dagang) dengan kadar alkohol yang tertera dalam kemasan adalah 14\%. Jenis minuman beredar di Manado dan yang dikonsumsi oleh anggota masyarakat (pengonsumsi alkohol) adalah Captikus dengan kadar alkohol 40-45\% dan Kasegaran (merek dagang) dengan kadar alkohol yang tertera dalam kemasan $17 \%$. 
Dengan demikian maka perbedaan dari dua jenis minuman yang mereka konsumsi ternyata berbeda pula reaksi hasil anestesi bagi para pasien. Rata-rata pasien yang mengonsumsi jenis minuman dengan kadar alkohol $\quad 14 \%$ (sampel Kotamobagu) sebagian besar tergolong cepat reaksi injeksi pada area anestesi yaitu bibir, lidah, mukosa bukal dan mukosa lingual, dibanding dengan reaksi anestesi pada anggota sampel yang menkonsumsi minuman beralkohol Captikus dan Kasegaran dengan kadar alkohol, 17\% sampai dengan $45 \%$.

Kegiatan anestesi dan ekstraksi yang dijalankan oleh dokter dalam proses pencabutan gigi yaitu; injeksi ampul pertama rata-rata diberikan 1,5 cc, kemudian pada menit ke empat dilakukan infiltrasi 0,5 cc. Perlakuan ini untuk semua pasien (sampel penelitian) dan proses observasi pada area teranestesi yaitu pada area bibir, area lidah, area mukosa bukal dan area mukosa lingual. Pencatatan observasi sampai pada menit dimana ke empat area tersebut tidak merasa sakit lagi, dan segera dilakukan ekstraksi. Dengan demikian maka seluruh anggota sampel penelitian mendapat perlakuan yang sama secara prosedural medik dan berbeda penanganan berdasarkan kasus yang dialami setiap pasien.

Keterkaitan antara kegiatan mengkonsumsi alkohol dengan data observasi anestesi dan ekstraksi dapat dilihat dalam rangkuman Tabel 12 sehingga dapat dilakukan analisis mengenai durasi waktu antara injeksi pertama dan infiltrasi dengan hilangnya rasa sakit pada saat dilakukan ekstraksi. Pada saat injeksi pertama dilakukan dicatat jam (menit) dan berdasarkan petunjuk dokter bahwa injeksi dilakukan dengan menggunakan ampul pehacain 1,5 cc yang kemudian dilanjutkan dengan infiltrasi pada menit ke IV, 0,5 cc.

Hasil observasi menunjukkan bahwa terdapat 3 orang anggota sampel (pasien) penelitian yang memiliki durasi 5 sampai dengan 6 menit, dihitung dari injeksi pertama. Ketiga pasien tersebut tergolong memiliki reaksi cepat hasil anestesi. Selanjutnya 3 orang anggota sampel penelitian memiliki durasi waktu 8 menit sampai dengan 15 menit dengan dua orang dilakukan injeksi dua kali dan satu orang hanya sekali dilakukan injeksi. Kelompok yang kedua ini memiliki durasi waktu tergolong sedang. Kemudian 4 orang anggota sampel (pasien) memiliki durasi waktu 18 menit sampai dengan 45 menit, dengan dilakukan injeksi ampul ke 2 sampai dengan ampul ke 4 (Tabel 13).

Dengan melihat Tabel 13 maka nampaklah bahwa yang rata-rata mengkonsumsi akohol sekitar 1 botol (Captikus) dan dua botol (Burung Sakti) durasi waktu 5 sampai 6 menit termasuk kategori cepat bereaksi, serta injeksi ratarata satu kali ditambah dengan infiltrasi.

Tabel 12. Jenis Minuman, volume minuman, injeksi, waktu reaksi dan ekstrasi

\begin{tabular}{cccccc}
\hline $\begin{array}{c}\text { Pasien } \\
(\mathrm{n})\end{array}$ & $\begin{array}{c}\text { Jenis } \\
\text { Minuman }\end{array}$ & $\begin{array}{c}\text { Jumlah } \\
\text { minuman }\end{array}$ & $\begin{array}{c}\text { Volume } \\
\text { Injeksi* }\end{array}$ & $\begin{array}{c}\text { Reaksi } \\
\text { Menit }\end{array}$ & $\begin{array}{c}\text { Ekstraksi } \\
\text { Menit ke }\end{array}$ \\
\hline 1 & CT \& KS & 1 & 1 & 5 & 6 \\
2 & CT \& KS & 1 & 2 & 18 & 19 \\
3 & CT \& KS & 3 & 2 & 8 & 9 \\
4 & CT \& KS & 1 & 2 & 21 & 22 \\
5 & CT \& KS & 2 & 4 & 45 & 55 \\
6 & BS & 2 & 1 & 8 & 9 \\
7 & BS & 2 & 1 & 6 & 7 \\
8 & BS & 2 & 3 & 23 & 24 \\
9 & BS & 2 & 1 & 6 & 7 \\
10 & BS & 2 & 2 & 15 & 16 \\
\hline
\end{tabular}


16 Jurnal e-GiGi (eG), Volume 1, Nomor 1, Maret 2013, hlm. 8-17

Tabel 13. Pengelompokan berdasarkan durasi waktu anestesi dengan ekstraksi

\begin{tabular}{cccccccc}
\hline $\begin{array}{c}\text { Pasien } \\
(\mathrm{n})\end{array}$ & $\begin{array}{c}\text { Kategori } \\
\text { durasi } \\
\text { waktu }\end{array}$ & $\begin{array}{c}\text { Jenis } \\
\text { Minuman }\end{array}$ & $\begin{array}{c}\text { Volume } \\
\text { minuman }\end{array}$ & $\begin{array}{c}\text { Volume } \\
\text { Injeksi* }\end{array}$ & $\begin{array}{c}\text { Onset } \\
\text { of } \\
\text { action }\end{array}$ & $\begin{array}{c}\text { Ekstraksi } \\
\text { Menit ke }\end{array}$ & $\begin{array}{c}\text { Duration } \\
\text { of } \\
\text { action }\end{array}$ \\
\hline 1 & cepat & CT \& KS & 1 & 1 & 5 & 6 & $5-6$ \\
7 & & BS & 1 & 1 & 6 & 7 & menit \\
9 & & BS & 2 & 1 & 6 & 7 & \\
\hline 3 & Sedang & CT \& KS & 3 & 2 & 8 & 9 & $8-15$ \\
6 & & BS & 2 & 1 & 8 & 9 & menit \\
10 & & BS & 2 & 2 & 15 & 16 & \\
\hline 2 & Lambat & CT\&KS & 2 & 2 & 18 & 19 & $19-55$ \\
4 & & CT\&KS & 2 & 2 & 21 & 22 & menit \\
5 & & CT\&KS & 2 & 4 & 54 & 55 & \\
8 & & BS & 2 & 3 & 23 & 24 & \\
\hline
\end{tabular}

*Infiltrasi tidak dihitung

Kategori sedang adalah yang meminum 2 sampai dengan 3 botol (Captikus, Kasegaran dan Burung Sakti) serta rata-rata ijeksi dua kali ditambah dengan infiltrasi. Kategori lambat reaksi adalah mereka yang rata-rata meminum alkohol lebih dari 2 botol, dilakukan injeksi 2 sampai 4 kali dengan durasi waktu 19 menit sampai dengan 55 menit. Dengan demikian maka terdapat perbedaan durasi massa bereaksi dihitung dari injeksi pertama sampai dengan waktu hilangnya rasa sakit pada saat dilakukan ekstraksi. Begitu pula terdapat perbedaan durasi waktu ketika anestesi dilakukan pada area bibir, lidah, mukosa bukal dan mukosa lingual berdasarkan jumlah alkohol yang diminum serta kandungan kadar alkohol.

Pasca pemberian anestesi dan ekstraksi dilakukan, maka rata-rata hilangnya efek anestesi memakan waktu 2 sampai 3 jam, dan setiap pasien memiliki perbedaan durasi waktu hilangnya rasa kebas yang berbeda. Perbedaan tersebut disebabkan pula oleh perbedaan durasi waktu pada saat dilakukan anestesi.

\section{SIMPULAN}

1. Kategori cepat bereaksi yaitu 3 orang pasien yang rata-rata mengonsumsi akohol 1 botol minuman Captikus dan dua botol minuman Burung Sakti. Kategori sedang yaitu 3 orang pasien yang rata-rata meminum 2 sampai dengan 3 botol minuman Captikus, Kasegaran dan Burung Sakti. Kategori lambat (lama) bereaksi berjumlah 4 orang dengan rata-rata mengonsumsi minuman beralkohol lebih dari 2 botol minuman Captikus, Kesegaran dan Burung Sakti.

2. Terdapat perbedaan durasi masa bereaksi dihitung dari injeksi pertama sampai dengan waktu hilangnya rasa sakit pada saat dilakukan ekstraksi. Begitu pula terdapat perbedaan durasi waktu ketika anestesi dilakukan pada area bibir, lidah, mukosa bukal dan mukosa lingual berdasarkan jumlah alkohol yang diminum serta kandungan kadar alkohol.

\section{DAFTAR PUSTAKA}

1. Minuman beralkohol [homepage on the Internet]. 2012 [cited 2012 May 14]. Available from: http://www.wikipedia.org.

2. Departemen Kesehatan Riset Kesehatan Dasar Laporan Nasional 2007. Badan Penelitian dan Pengembangan Kesehatan Republik Indonesia [homepage on the Internet]. 2008 [cited 2012 May 14]. Available from: http://www.k4health. org/sites/default/files/laporanNasional\%20Ri skesdas\%202007.pdf

3. Wardjowinoto S. Interaksi fakmakokinetik alkohol dengan obat - obatan. Jurnal XXXIV Laboratorium Farmasi Kedokteran FK Unair. 1998.h.26. 
Gugule, Posangi, Mariati; Gambaran Efek Pemberian Anestesi Lokal... 17

4. Alkohol apa yang membahayakan [homepage on the Internet]. 2010 [cited 2012 Mar 16]. Available from: http://gegtriee.wordpress.com/.

5. Ayunis D. Anastesi pada pasien alkoholik. [skripsi]. Fakultas Kedokteran Universitas Yarsi; 2011; p.3.

6. Tinjauan pustaka anestesi. USU Press [homepage on the Internet]. 2011 [cited 2012
May 14]. Available from: http://repository.usu.ac.id/bitstream/1234567 89/24912/4/Chapter II.pdf

7. Notoatmodjo S. Metodologi penelitian kesehatan. Jakarta: PT. Rineka Cipta; 2010.

8. Azwar A, Prihartono J. Metode penelitian kedokteran dan kesehatan masyarakat. Jakarata: PT. Binarupa Aksara; 2003. 